UDC 666.972.16

\title{
Algorithm of Plastic Concrete Crack Resistance is Calculation under Capillary Shrinkage Using Generalizing Criteria
}

\author{
S. N. Leonovich ${ }^{1)}$ \\ ${ }^{1)}$ Belarusian National Technical University (Minsk, Republic of Belarus)
}

\begin{abstract}
The method of concrete crack-resistance prediction at early age is developed at capillary shrinkage with use of approaches of fracture mechanics, which is guided by the concept of accumulation of defects in structure in the form of capillaries and cracks to their critical concentration of $C_{c}$. At the same time process at two stages is considered: on the first - process of formation and growth of defects and on the second - the process, which is directly accompanying destructions (fragmentation) at critical concentration of defects. As a theoretical basis of a method physical ideas of the increment volume mechanism of hollowness of cracks in the concrete model, presented as two-level structure are accepted: a matrix of the hardened cement stone with inclusions and emptiness of various form (crack) as result of the external influences, changing the intense deformed state. The main criterion of a method - the generalized total parameter of crack-resistance $K_{c}=\sqrt{K_{\mathrm{Ic}}^{2}+K_{\mathrm{II} c}^{2}}$, calculated on the basis of model schemes of growth, association, localization of cracks system, their classification by types and relative quantity in volume at the initial concentration increasing to critical, that is caused by physical processes of capillary shrinkage is established. Being based on the considered regularities of process of concrete destruction, it is offered to divide all defects of structure, both initial, and developed as a result of power and not power influences, into 5 main types. The amount of pores and cracks of the first four types depends on concrete porosity, and type $\mathrm{V}$ - and on the volume content of grains of small or coarse aggregate. To each type of damages, there corresponds the stress intensity factor, extent of influence and which value on the general crack resistance of material depend on quantity of this type of pores and cracks in concrete volume. The new evidence-based algorithm of crack resistance calculation at concrete shrinkage at early age by the generalized criterion, which contains the sequence of operations of calculation as for selection of structure, taking into account the factors, influencing capillary pressure and according to characteristics of properties of concrete components, its technological parameters, and for residual resource definition of concrete on its structure and properties, and also on the samples, which are selected from structures at early age is offered.
\end{abstract}

Keywords: algorithm, calculation, crack-resistance, plastic (early age) concrete, capillary shrinkage, generalizing criteria, stress intensity factor

For citation: Leonovich S. N. (2018) Algorithm of Plastic Concrete Crack Resistance is Calculation under Capillary Shrinkage Using Generalizing Criteria. Science and Technique. 17 (6), 502-507. https://doi.org/10.21122/2227-1031-2018$17-6-502-507$

\section{Алгоритм расчета трещиностойкости бетона в раннем возрасте при капиллярной усадке по обобщенному критерию}

\author{
Докт. техн. наук, проф. С. Н. Леонович ${ }^{1)}$ \\ ${ }^{1)}$ Белорусский национальный технический университет (Минск, Республика Беларусь) \\ (C) Белорусский национальный технический университет, 2018 \\ Belarusian National Technical University, 2018
}

Реферат. Разработан метод расчета трещиностойкости бетона в раннем возрасте при капиллярной усадке с использованием подходов механики разрушения, который опирается на концепцию накопления дефектов в структуре в виде

\section{Адрес для переписки}

Леонович Сергей Николаевич

Белорусский национальный технический университет просп. Независимости, 150,

220014, г. Минск, Республика Беларусь

Тел.: +375 17 265-96-76

leonovichsn@tut.by

\author{
Address for correspondence \\ Leonovich Sergey N. \\ Belarusian National Technical University \\ 150 Nezavisimosty Ave., \\ 220014, Minsk, Republic of Belarus \\ Tel.: +375 17 265-96-76 \\ leonovichsn@tut.by
}


пор, капилляров и трещин до их критической концентрации $C_{c}$. При этом рассматривается процесс на двух стадиях: на первой - процесс образования и развития дефектов и на второй - процесс, непосредственно сопровождающий разрушения (фрагментацию) при критической концентрации дефектов. В качестве теоретической основы метода приняты физические представления о механизме приращения объема пустотности трещин в модели бетона, представленной как двухуровневая структура: матрица затвердевшего цементного камня с включениями и пустоты различной формы (трещины) как результат внешних воздействий, изменяющих напряженно-деформированное состояние. Установлен основной расчетный критерий метода - обобщенный суммарный параметр трещиностойкости $K_{c}=\sqrt{K_{\mathrm{Ic}}^{2}+K_{\mathrm{II} c}^{2}}$, вычисляемый на основании модельных схем развития, объединения, локализации системы трещин, их классификации по видам и относительному количеству в объеме при начальной концентрации, возрастающей до критической, что обусловлено физическими процессами капиллярной усадки. Базируясь на рассмотренных закономерностях процесса разрушения бетона, предложено разделить все дефекты структуры, как исходные, так и развившиеся в результате силовых и несиловых воздействий, на пять основных типов. Содержание пор и трещин первых четырех типов зависит от пористости бетона, а типа V - и от объемного содержания зерен мелкого или крупного заполнителя. Каждому виду повреждений соответствует свой коэффициент интенсивности напряжений, степень влияния и величина которого на общую трещиностойкость материала зависят от количества данного вида пор и трещин в объеме бетона. Предложен новый научно обоснованный алгоритм расчета трещиностойкости при усадке бетона в раннем возрасте по обобщенному критерию, содержащий последовательность операций расчета как для целей подбора состава с учетом влияющих на капиллярное давление факторов и по характеристикам свойств компонентов бетона, его технологическим параметрам, так и для определения остаточного ресурса бетона по его составу и свойствам, а также по образцам, отобранным из конструкций в раннем возрасте.

Ключевые слова: алгоритм, расчет, трещиностойкость, пластический бетон (в раннем возрасте), капиллярная усадка, обобщенный критерий, коэффициент интенсивности напряжений

Для цитирования: Леонович, С. Н. Алгоритм расчета трещиностойкости бетона в раннем возрасте при капиллярной усадке по обобщенному критерию / С. Н. Леонович // Наука и техника. 2018. Т. 17, № 6. С. $502-507$. https://doi.org/10.21122/2227-1031-2018-17-6-502-507

\section{Definition of the main crack-resistance characteristics of concrete at any level of its hierarchical structure}

Stress intensity factor in top of defect in material, which structure contains others micro and macrodamages, reflect in the numerical value influence of these damages on the intense deformed state as around defect, and all volume of material. It is possible to consider this total influence, having considered everything micro and macrodefects at all levels of a hierarchical structure of a composite. Each of pores and cracks in concrete creates a certain field of tension around itself. If to consider, that this pores and cracks settle down in volume of concrete with some frequency, fields of tension and deformations are imposed at each other that creates the difficult intense deformed state. Being based on [1-10] regularities of process of destruction of concrete considered above, we will divide all defects of structure, both initial, and developed as a result of power and not power influences, into five main types:

1 - roundish emptiness - pores with the submicrocracks, coming to their borders formed as a result of concentration of tension around a circular opening;

2 - ellipse emptiness - pores with the microcracks coming to their borders;
3 - mezocracks in a concrete body (type 1);

4 - regional cracks (type II);

5 - radial and contact cracks around grains and inclusions (types III and IV).

Content of emptiness - pores and cracks of types 1-4 depends on porosity of concrete, and 5 and on the volume content of grains of small or coarse aggregate, and these cracks on border of a cement stone and grains of filler characterize meso- and the macro-level of consideration of concrete structure. The volume amount of each type of emptiness - pores and cracks depending on porosity of material and volume content of filler is defined experimentally. To each type of damages there corresponds the value of stress intensity factor, extent of influence and which value on the general crack resistance of material depends on quantity of this type of pores and cracks in concrete volume. Applying the principle of independence of action of forces and considering, that emptiness - pores and cracks are distributed evenly on all volume of material, it is possible to write down:

- for submicro, micro and mesolevels

$$
K_{\mathrm{I}}=n_{1} K_{\mathrm{I}}^{1}+n_{2} K_{\mathrm{I}}^{2}+n_{3} K_{\mathrm{I}}^{3}+\left(1-n_{1}-n_{2}-n_{3}\right) K_{\mathrm{I}}^{4},
$$

where $K_{\mathrm{I}}^{1}, K_{\mathrm{I}}^{2}, K_{\mathrm{I}}^{3}, K_{\mathrm{I}}^{4}$ - stress intensity factor respectively in tops of microdefects $1,2,3$ and $4 ; n_{1}$, $n_{2}, n_{3}$ - content of microdefects of 2 and 3 types in total of microdamages; 
- for meso- and macrolevels

$$
\begin{aligned}
K_{\mathrm{I}}= & n_{1} K_{\mathrm{I}}^{1}+n_{2} K_{\mathrm{I}}^{2}+n_{3} K_{\mathrm{I}}^{3}+n_{4} K_{\mathrm{I}}^{4}+ \\
& +\left(1-n_{1}-n_{2}-n_{3}-n_{4}\right) K_{\mathrm{I}}^{5},
\end{aligned}
$$

$K_{\mathrm{I}}^{5}$ - stress intensity factor in tops of radial and contact cracks on border with grains of small and coarse aggregate; $n_{4}$ - the amount of regional cracks in total of damages.

Sizes $K_{\mathrm{I}}^{1}-K_{\mathrm{I}}^{5}$ are calculated according to tab. 1, depending on the content of emptiness pores and cracks of this type in total of damages. Then it is final:

- for submicro, micro and mesolevels

$$
\begin{aligned}
K_{\mathrm{I}}= & p \sqrt{\pi}\left\{n_{1} A \sqrt{L_{1}\left(1+R /\left(R+L_{1}\right)\right)}+\right. \\
& +n_{2} B \sqrt{a+L_{2}}+n_{3} C \sqrt{L_{3}}+ \\
& \left.+\left(1-n_{1}-n_{2}-n_{3}\right) D \sqrt{L_{4}}\right\},
\end{aligned}
$$

where $R=5 \cdot 10^{-7} \mathrm{~m} ; L_{1}=1 \cdot 10^{-8} \mathrm{~m} ; L_{2}=1 \cdot 10^{-8}$ $\mathrm{m} ; L_{3}=5 \cdot 10^{-5} \mathrm{~m} ; L_{4}=5 \cdot 10^{-5} \mathrm{~m} ; a=5 \cdot 10^{-6} \mathrm{~m}$; $L_{1}-L_{4}$ - semi-length (length) of defects or emptiness - pores; $A, B, C, D$ - coefficients, specified in tab. 1 over line;

- for meso- and macrolevels

$$
K_{\mathrm{I}}=p \sqrt{\pi}\left\{n_{1} A \sqrt{L_{1}\left(1+R /\left(R+L_{1}\right)\right)}+\right.
$$

$$
\begin{gathered}
+n_{2} B \sqrt{a+L_{2}}+n_{3} C \sqrt{L_{3}}+ \\
\left.+n_{4} D \sqrt{L_{4}}+\left(1-n_{1}-n_{2}-n_{3}-n_{4}\right) E \sqrt{L_{5} / 2}\right\},
\end{gathered}
$$

$R=5 \cdot 10^{-7} \mathrm{~m} ; \quad L_{1}=1 \cdot 10^{-8} \mathrm{~m} ; \quad L_{2}=1 \cdot 10^{-8} \mathrm{~m} ;$ $L_{3}=5 \cdot 10^{-3} \mathrm{~m} ; \quad L_{4}=5 \cdot 10^{-3} \mathrm{~m} ; \quad L_{5}=D_{\max }^{a g}$; $a=5 \cdot 10^{-6} \mathrm{~m} ; D_{\max }^{a g}-$ maximum diameter of grain of small or coarse aggregate in a concrete matrix; $L_{5}$ - length of a radial crack; $E$ - coefficient, specified in tab. 1 over line.

The size $K_{\mathrm{II}}$ can be determined on coefficients of $C, D$ and $E$, provided in tab. 1 below the line. We will note, that shift tension in tops of emptyness - pores of types 1 and 2 doesn't arise. Then:

- on submicro, micro and mesolevels

$$
K_{\mathrm{II}}=n_{3} K_{\mathrm{II}}^{3}+\left(1-n_{3}\right) K_{\mathrm{II}}^{4} ;
$$

- on meso- and macrolevels

$$
K_{\mathrm{II}}=n_{3} K_{\mathrm{II}}^{3}+n_{4} K_{\mathrm{II}}^{4}+\left(1-n_{3}-n_{4}\right) K_{\mathrm{II}}^{5},
$$

\begin{tabular}{|c|c|c|c|c|c|}
\hline $\begin{array}{l}\text { Amount } \\
\text { of pores } \\
n_{1}-n_{5}, \%\end{array}$ & 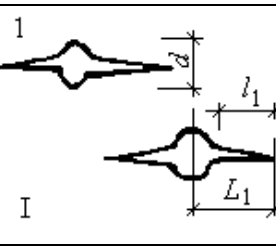 & $\underbrace{2} \frac{x^{l_{2}}}{t_{L_{2}}}$ & & ${ }^{4}$ & III and IV \\
\hline & $\begin{array}{c}K_{\mathrm{IC}}= \\
=\sigma_{b} \sqrt{\pi l_{1}\left(1+d / L_{1}\right)}\end{array}$ & $\begin{array}{c}K_{\mathrm{IC}}=\sigma_{b} \sqrt{\pi_{1}\left(a+l_{2}\right)} \\
K_{\mathrm{IC}}=\sigma_{b} \sqrt{\pi l_{2}\left(1+d / L_{2}\right)}\end{array}$ & $\begin{array}{l}K_{\mathrm{IC}}=\sigma_{b} \sqrt{\pi l_{3}} \\
K_{\mathrm{IIC}}=C \tau \sqrt{\pi l_{3}}\end{array}$ & $\begin{aligned} K_{\mathrm{IC}} & =\sigma_{b} \sqrt{\pi l_{4}} \\
K_{\mathrm{IIC}} & =D \tau \sqrt{\pi l_{4}}\end{aligned}$ & $\begin{aligned} K_{\mathrm{I}} & =\sigma_{b} \sqrt{\pi l_{5} / 2} \\
K_{\mathrm{IIC}} & =E \tau \sqrt{\pi l_{5} / 2}\end{aligned}$ \\
\hline & $A$ & $B$ & $C$ & $D$ & $E$ \\
\hline 5 & 1.733 & 1.0550 & $1.0122 / 1.0205$ & $0.2303 / 0.2004$ & $0.643 / 0.060$ \\
\hline 10 & 1.912 & 1.1003 & $1.0212 / 1.0417$ & $0.3116 / 0.1997$ & $0.651 / 0.061$ \\
\hline 15 & 2.067 & 1.2794 & $1.0480 / 1.0630$ & $0.3992 / 0.1901$ & $0.657 / 0.063$ \\
\hline 20 & 2.235 & 1.4212 & $1.0647 / 1.0890$ & $0.4570 / 0.1762$ & $0.682 / 0.068$ \\
\hline 25 & 2.506 & 1.6517 & $1.1010 / 1.1812$ & $0.5640 / 0.1592$ & $0.701 / 0.072$ \\
\hline 30 & 2.973 & 1.8432 & $1.1535 / 1.2810$ & $0.6810 / 0.1446$ & $0.793 / 0.081$ \\
\hline 35 & 3.084 & 2.0020 & $1.4032 / 1.4216$ & $0.7632 / 0.1410$ & $0.854 / 0.087$ \\
\hline 40 & 3.512 & 2.1760 & $1.5547 / 1.5732$ & $0.8720 / 0.1337$ & $0.892 / 0.092$ \\
\hline
\end{tabular}

where the characteristic sizes of cracks 3-5 are accepted for each of consideration levels according to (1) and (2).

We determine a material constant $K_{C}$ by a formula

$$
K_{C}=\sqrt{\sum K_{\mathrm{I}}^{2}+\sum K_{\mathrm{II}}^{2}}
$$

Stress intensity factors taking into account the content of emptiness, capillaries, cracks in a cement stone 


\section{An algorithm of concrete crack-resistance calculation at early age at capillary shrinkage by the generalized criterion}

The method of calculation of early age concrete crack-resistance is developed at capillary shrinkage with use of approaches of fracture mechanics, which is guided by the concept of accumulation of defects in structure in the form of pores, capillaries and cracks to their critical concentration of $C_{c}$. At the same time process at two stages is considered: on the first - process of formation growth of defects and on the second - the process, which is directly accompanying destructions (fragmentation) at critical concentration of defects.

As a theoretical basis of a method physical ideas of the increment volume mechanism of hollowness of cracks in the model of concrete, presented as two-level structure are accepted: a matrix of the hardening cement stone with inclusions and emptiness of various form (crack) as result of the external influences, changing the intense deformed state.

The main criterion of a method - the generalized total parameter of crack resistance of $K_{c}=\sqrt{K_{\mathrm{I} c}^{2}+K_{\mathrm{II} c}^{2}}$ calculated on the basis of model schemes of growth, association, localization of system of cracks, their classification by types and relative quantity in volume at the initial concentration, increasing to critical, that is caused by capillary shrinkage is established.

The algorithm of crack-resistance calculation at shrinkage contains the sequence of operations as for selection of structure for the known factors and characteristics of concrete components proper- ties, their technological parameters, influencing capillary pressure in early age, and for definition of a residual resource of concrete on the samples, which are selected from structures at early age in the conditions of curing.

The algorithm includes.

1. Basic data about design parameters of external influences: power $(N, M, Q)$ and not power $(t, W, P)$ influences; about components concrete characteristics cement $\left(R_{c}\right)$, filler $\left(R_{a}\right)$, chemical additives.

2. Data on concrete properties, its durability of $R_{b}$ and $R_{b t}$, elasticity of $E_{b}$, crack resistance of $R_{c r c}^{0}$ and $R_{c r c}^{v}$ at early age.

3. Operations on calculation of concrete porosity (the general, capillary, gel, content).

4. Operations on calculation of $K_{\mathrm{I} i}^{b}, K_{\mathrm{II} i}^{b}$ in tops of defects of the $\mathrm{I}-\mathrm{V}$ types at capillary shrinkage.

5. Operations on calculation of criterion of SIF at shrinkage (temperature and moist influences), taking into account distribution of pores and capillaries in total of defects.

6. Calculation of the KIN limit value for this structure.

7. Calculation of the module of elasticity $E_{b}$ for this structure.

8. Calculation of crack-resistance of concrete, taking into account shrinkage (thermo-moist influences).

9. Operations of assessment of result and correction of structure.

The algorithm of calculation of durability is presented in fig. 1 .

\begin{tabular}{|c|l|}
\hline 1 & $\begin{array}{l}\text { Basic data: a) design parameters external power }(N, M, Q) \text { and not power }(t, W, P, \text { concentration } \\
\text { of chemicals) influences; } \\
\text { b) characteristics component of concrete: of cement }\left(R_{c}\right) \text {, aggregate }\left(R_{a}\right), \text { chemical additives }\end{array}$ \\
\hline \multicolumn{2}{|c|}{ The required (design) service life } \\
\hline 2 & $\begin{array}{l}\text { Calculation of content (recepture) of concrete for strength }\left(R, R_{b t}\right), \text { deformability }\left(E_{b}\right) \text { and crack-resistance } \\
\text { of } R_{c r c}^{0}\end{array}$ \\
\hline 3 & $\begin{array}{l}\text { Calculation for the picked-up composition of concrete of its porosity; the general, gel, capillary, differential } \\
\text { porosity of a cement stone and concrete }\end{array}$ \\
\hline
\end{tabular}

Fig. 1. An algorithm of calculation of crack resistance of early age concrete at capillary shrinkage (see also p. 506) 
$\downarrow$

$4 \quad$ Calculation of stress of intensity factors of SIF in tops of defects of the I-V ltypes at shrinkage (temperature and moist influences)

\begin{tabular}{|c|c|}
\hline $\begin{array}{l}\text { I tempera- } \\
\text { ture range } \\
\text { (water) }\end{array}$ & $\begin{array}{l}K_{\mathrm{I}, t}^{\mathrm{I}, 1, c}=\frac{4 \sqrt{\pi}}{\sqrt{2}} \frac{a_{c} \cos \theta \cdot \sigma_{0}\left(1-t / t_{k}\right)}{g_{c} \sqrt{l_{c}\left[1-(1-W / 100)^{2}\right]}} ; \quad K_{\mathrm{I}, t}^{\mathrm{I}, 1, w}=\alpha_{t, w} \Delta t E_{w} \sqrt{\pi l_{c} / 2}\left[1-(2 / \pi) \arcsin \left(2 b_{c} / l_{c}\right)\right] ; \\
K_{\mathrm{I}, t}^{\mathrm{I}, 1, c s}=\alpha_{t, c s} \Delta t E_{c s} \sqrt{\pi l_{c} / 2} ; \quad K_{\mathrm{I}, t}^{\mathrm{I}, 1, c, m}=P_{c} \sqrt{2} / \sqrt{\pi\left(l^{2}-4 b^{2}\right)} ; \\
K_{\mathrm{I}, t}^{\mathrm{I}, 1, w, m}=\alpha_{t, w} \Delta t E_{w} \sqrt{\pi l_{c} / 2 \pi}\left[(\pi / 2)-\arcsin \left(2 b_{c} / l_{c}\right)\right] ; \\
K_{\mathrm{I}, t}^{\mathrm{I}, 1, w}=2 P_{w} \sqrt{l_{c} / \pi} \arccos \left(b_{c} / l_{c}\right)\left[1+0,1215\left(1-b_{c} / l_{c}\right)\right] ; \quad K_{\mathrm{I}, t}^{\mathrm{II}, 1, c s}=3,523 \alpha_{t, c s} \Delta t E_{c s} \sqrt{l_{c} / \pi}\end{array}$ \\
\hline \multicolumn{2}{|r|}{ For a crack on contact with filler (aggregate) } \\
\hline$K_{\mathrm{I}, t}^{\mathrm{III}}=P \sqrt{\pi l}$ & $\left.\frac{\left[1-\alpha(r) f(l / R)(M-R)^{2}\right]}{\left[(M-R)^{2}-r^{2}\right]}\right\}(1+g)$ \\
\hline \multicolumn{2}{|c|}{$\begin{array}{l}K_{\mathrm{I}, t}^{\mathrm{IY}}=2 p(1+\alpha)^{-1} \sqrt{\pi R \sin \theta}\left\{G_{2}\left(1+X_{1}\right)\left[G_{1}\left(1+X_{2}\right)+G_{2}\left(1+X_{1}\right)\right] e^{\beta(\theta+\pi)}\right\} /\left\{\left(G_{2}+G_{1} X_{2}\right)\left[G_{1}\left(1+X_{2}\right)+2 G_{2}\left(1+X_{1}\right)\right]-\right. \\
\left.-G_{1}\left(1+X_{2}\right)\left(G_{1}+G_{2} X_{1}\right)(\cos \theta-2 \beta \sin \theta) e^{-2 \beta \theta}\right\} ; \\
K_{\mathrm{II}, t}^{\mathrm{IY}}=2 p R^{\beta}(1+\alpha)^{-1} \sqrt{\pi R \sin \theta}\left\{G_{2}\left(1+X_{1}\right)\left[G_{2}\left(1+X_{1}\right)+G_{1}\left(1+X_{2}\right)\right](1-2 \beta) e^{\beta(\theta+\pi)} e^{-\beta \ln 2 \sin \theta}\right\} /\left\{\left(G_{2}+G_{1} X_{1}\right) \times\right. \\
\left.\times\left[G_{1}\left(1+X_{2}\right)+2 G_{2}\left(1+X_{1}\right)\right]-G_{1}\left(1+X_{2}\right)\left(G_{1}+G_{2} X_{1}\right)(\cos \theta-2 \beta \sin \theta) e^{-2 \beta \theta}\right\}\end{array}$} \\
\hline
\end{tabular}

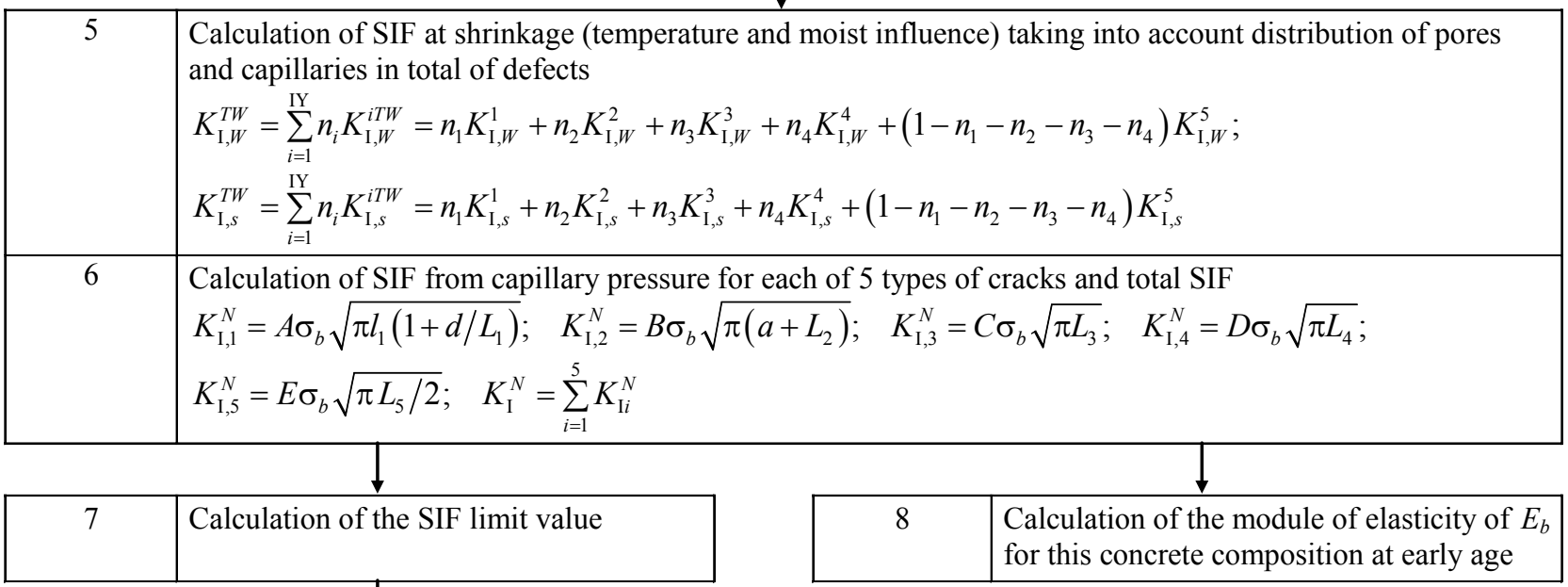

$9 \quad$ Calculation of crack resistance at early age at capillary shrinkage $t=2\left(K_{\mathrm{I} c}^{c r}-K_{\mathrm{I}}^{N}\right) /\left|K_{\mathrm{I}, W}^{T W}-K_{\mathrm{I}, s}^{T W}\right| \psi$

Fig. 1. Engding

\section{CONCLUSIONS}

1. At theoretical justification of a method of crack-resistance calculation at capillary shrinkage of early age concrete with use of approaches of fracture mechanics by the generalized criterion the main assumptions are formulated.
2. The developed model is the hierarchical system, suitable for the description of processes of destruction (destruction) of early age concrete at any levels of consideration of its structure. Having entered the corresponding characteristics for materials of filler and cement and sand solution, it is 
possible to receive deformative, strength characteristics, parameters of the concrete cracks in case of change of its humidity and temperature (at shrinkage).

3. Being based on the considered regularities of concrete destruction process, it is offered to divide all defects of structure, both initial, and developed as a result of power and not power influences, into 5 main types. The amount of pores and cracks of the first four types depends on concrete porosity, and type $\mathrm{V}$ - and on the volume content of grains of small or coarse aggregate. To each type of damages, there corresponds the stress intensity factor, extent of influence and which value on the general crack resistance of material depend on quantity of this type of pores and cracks in concrete volume.

4. The new evidence-based algorithm of crackresistance calculation at shrinkage of early age concrete by the generalized criterion, which contains the sequence of operations of calculation as for selection of structure, taking into account the factors, influencing capillary pressure and according to characteristics of properties of concrete components, its technological parameters, and for definition of concrete residual resource on its structure and properties and also on the samples, which are selected from structures at early age is offered.

\section{REFERENCES}

1. Leonovich S. N. (2018) Modeling of Capillary Shrinkage and Crack Formation of Concrete at Early Age. Nauka $i$ Tekhnika = Science\&Technique, 17 (4), 265-277. https://doi. org/10.21122/2227-1031-2018-17-4-265-277.

2. Leonovich S. N., Litvinovskii D. A., Chernyakevich O. Yu., Stepanova A. V. (2016) Strength, Crack Resistance and Durability of Constructional Concrete at Corrosive and
Temperature Attacks. 2 Volumes. Minsk, Belarusian National Technical University (in Russian).

3. Leonovich S., Shalyi E., Falaleeva N., Kim L. (2016) The Influence of Carbon Dioxide on the Durability of Offshore Concrete. 26 International Ocean and Polar Engineering Conference, ISOPE-2016, Rhodes, Greece, June 26-July 1, 2016.

4. Leonovich S., Zaitsev Yu., Tsuprik V., Kim L. (2016) Frost Destruction and Fracture Mechanics of Concrete. Polyarnaya Mekhanika: Materialy Tret'ei Mezhdunar. Konf., 27-30 Sent. 2016, Vladivostok [Polar Mechanics: Materials of Third International Conference, September 27-30, 2016, Vladivostok]. Vladivostok, Far Eastern Federal University, 687-693.

5. Snezhkov D. Yu., Leonovich S. N. (2016) Monitoring of Built and Operated Reinforced Concrete Structures by Nondestructive Methods. Minsk, Belarusian National Technical University. 330 (in Russian).

6. Snezhkov D. Yu., Becker A. T., Leonovich S. N., Kim L. V. (2016) Control of Steel Concrete Constructions by Nondestructive Methods. Vladivostok, Far Eastern Federal University. CD-ROM (in Russian).

7. Zaytsev Yu. V., Leonovich S. N., Schneider U. (2011) Structure, Durability and Fracture Mechanics of Concrete at Two-Axis and Three-Axis Compression. Minsk, Belarusian National Technical University. 381 (in Russian).

8. Eberhardsteiner Y., Leonovich S., Zaytsev Yu. V. N. (2013) Strength, Crack-Resistance and Durability of Constructional Construction Materials at Difficult Tension. Minsk, Belarusian National Technical University. 522 (in Russian).

9. Leonovich S. N., Litvinovsky D. A., Kim L. V. (2015) Strength, Crack Resistance and Durability of Constructional Concrete at Influence of High Temperatures. Vladivostok, Far Eastern Federal University. 148 (in Russian).

10. Zemlyakov G. V., Knyazev M. A., Trofimenko E. E., Leonovich S. N. (2012) Two-Solitonic Solution of Task about Destruction of Core. Doklady Natsional'noi Akademii Nauk Belarusi = Doklady of the National Academy of Sciences of Belarus, 56 (3), 87-91 (in Russian).

Received: 10.03.2017

Accepted: 05.05.2017

Published online: 30.11.2018 